\title{
Editorial
}

\section{Gênero e violência contra a mulher no Exame Nacional do Ensino Médio: avanço e polêmica}

Nestes últimos meses o meio político e educacional e a própria sociedade brasileira, de modo geral, se viram diante de uma discussão no mínimo inusitada para o momento: as questões de gênero e da violência contra a mulher como tema constante do Exame Nacional do Ensino Médio.

Por que tanta polêmica a esse respeito? Trata-se de um assunto que, supostamente, já deveria estar superado e consolidado em nossa sociedade dadas as diretrizes nacionais apontadas na Política Nacional de Atenção Integral à Saúde da Mulher. Aí estão definidas e explicitadas a questão da igualdade de gênero como princípio norteador das ações de saúde para a mulher e para todo e qualquer cidadão brasileiro. Do mesmo modo está explicitada a questão do combate e prevenção da violência contra a mulher como um de seus desdobramentos mais significativos, através da Política Nacional de Enfrentamento da Violência Contra as Mulheres.

Mais ainda, a questão de gênero extrapola em muito o âmbito da mulher em nossa sociedade e adentra o universo de outros grupos e minorias a ela relacionadas, tais quais gays, homossexuais, lésbicas, bissexuais, transgêneros, travestis. Os direitos iguais jamais serão para todos se não forem entendidos como iguais para todos os cidadãos brasileiros, e também para os que aqui habitam por direito de imigração, independente do gênero, raça/ cor da pele ou crença religiosa.

Portanto, entendemos como acertada a decisão pela inclusão destes temas no Exame Nacional do Ensino Médio. Trouxe para a juventude, que pretende seu ingresso na universidade e na vida acadêmica, a necessidade de um posicionamento a este respeito. No mínimo despertou a curiosidade para buscar no espaço acadêmico essa discussão com pensadores e cientistas.

O que se observou, no entanto, foi o afloramento, explícito e violento, de preconceitos e ressentimentos que vem sendo sistematicamente retomados, reforçados ou incentivados por uma parcela da população que, em diferentes situações ou posições ocupadas, aproveita-se do fato para dar vazão às suas ideias retrógradas. Nesse grupo encontram-se, por exemplo, parlamentares em todos os níveis, lideranças religiosas, membros de entidades da sociedade civil organizada e cidadãos comuns, uns incentivados pelos outros.

As redes sociais constituíram veículo de disseminação rápida do ponto de vista desses grupos. Computadores, tablets e telefones celulares inundaram-se de mensagens e postagens apregoando e defendendo o preconceito e a discriminação. Ao mesmo tempo, foi através dessas mesmas redes sociais que se levantaram as vozes expressando fortemente o repúdio e a rejeição a essas ideias e atitudes.

Às comunidades científica e acadêmica, incluindo-se aqui a enfermagem, cabe promover o debate, e quem sabe participar na mediação dessa discussão, produzindo o conhecimento indispensável à superação das desigualdades sociais e à garantia dos direitos dos cidadãos.

Os periódicos científicos são os porta-vozes da comunidade acadêmica competindo-lhes difundir o conhecimento ali produzido. Seu corpo editorial tem a responsabilidade/dever selecionar e decidir, entre todos os manuscritos recebidos, aqueles que atendem aos critérios éticos, científicos e padrões acadêmicos, bem como à confiabilidade da informação para sua publicação.

Entendemos que esse episódio reforça nossa responsabilidade e chama nossa atenção para o cuidado mínimo indispensável, no processo de seleção do material a ser publicado para identificar aqueles que efetivamente contribuam para a superação da desigualdade/inequidade de gênero, em detrimento da propagação do preconceito e da discriminação. Esse, sem dúvida alguma, é o compromisso da Revista Enfermagem UERJ.

Octavio Muniz da Costa Vargens Editor Científico 
